\title{
Reaktualisasi Pemikiran Umar bin Abdul Aziz Dalam Manajemen Penganggaran Publik
}

\author{
Muhamad Yusup \\ Universitas Islam Negeri Mataram \\ muhamadyusup@,uinmataram.ac.id
}

\begin{abstract}
Abstrak
Manajemen penganggaran publik diperlukan untuk melahirkan paradigma baru dari traditional budget menuju performance budget. Implementasi penganggaran publik saat ini tidak sepenuhnya sesuai dengan perencanaan, pelaksanaan, dan evaluasi penganggaran, karena minimnya keterlibatan masyarakat. Besarnya postur anggaran belanja pada bidang tertentu menjadikan tidak terlaksananya pembangunan dengan baik. Menelaah pemikiran Umar bin Abdul Aziz dalam manajemen penganggaran publik memberikan wacana baru tentang bagaimana pola penganggaran publik yang memiliki konsep prinsip dasar bahwa segala bentuk kekayaan yang dikelola oleh negara adalah untuk kepentingan rakyat, dengan memaksimalkan sumber pendapatan yang berorientasi pada prinsip mashlahah dan menghindari masyaqqah. Sumber pendapatan dimaksud adalah optimalisasi potensi zakat, infaq, dan shadaqah sebagai pendapatan asli. Implikasi teorinya, bahwa tidak ada perbedaan antara penganggaran dalam perspektif Islam maupun penganggaran pada umumnya berdasarkan kaidah tasarruf al-imam ala ra'iyyah manutun bi al-maslahah. Perpaduan kedua konsep dan teori tersebut menghasilkan pola baru dalam manajemen penganggaran publik, yang berorientasi pada mashlahah, berkeadilan, menghindari masyaqqah, dan memiliki keseimbangan untuk mencapai kesejahteraan dan kemakmuran rakyat.
\end{abstract}

Kata Kunci: Reaktualisasi, Manajemen, Penganggaran, Publik

\section{PENDAHULUAN}

Perubahan global semakin besar pengaruhnya pada reformasi praktik penyelenggaraan pemerintahan di negara-negara berkembang, termasuk di Indonesia. Salah satu aspek reformasi yang mendapat perhatian di Indonesia hingga kini adalah persoalan manajemen penganggaran publik disamping manajemen pemerintahan secara umum. Manajemen pemerintahan sudah barang tentu berkaitan dengan manajemen penganggaran publik. Praktik manajemen penganggaran publik memiliki fokus pada pengelolaan keuangannya yang terbagi menjadi dua bagian, yaitu manajemen penerimaan anggaran dan manajemen pengeluaran anggaran. Evaluasi terhadap kedua bagian tersebut termasuk pengelolaan keuangan dan pembiayaan pembangunan yang memiliki implikasi yang sangat luas, kesemuanya sangat menentukan kedudukan suatu pemerintahan dalam rangka melaksanakan kewajiban kepada masyarakat (Nawawi, 2010). 
Yusup. Manajemen Penganggaran Publik

Perubahan tersebut antara lain, perlunya dilakukan budgeting reform atau reformasi manajemen penganggaran (Mardiasmo, 2002). Reformasi manajemen penganggaran meliputi proses perencanaan, penyusunan, penetapan, pengesahan, pelaksanaan, dan pertanggungjawaban atau evaluasi penganggaran. Aspek utama budgeting reform adalah perubahan dari traditional budget ke performance budget. Traditional budget didominasi oleh penyusunan anggaran yang bersifat line-item dan instrumentalism, yaitu proses penyusunan anggaran yang hanya berorientasi pada anggaran yang baru, dan hal ini bertentangan dengan kebutuhan dan keinginan masyarakat. Dengan orientasi pada manajemen penganggaran tersebut, penganggaran pemerintah dianggap masih berorientasi pada subordinasi kepentingan politis. Di samping itu, kinerja penganggaran (performance budget) yang didalanmnya merupakan kinerja pada sistem penyusunan dan pengelolaan penganggaran harus berorientasi pada pencapaian hasil kinerja. Dan dengan pencapaian hasil kinerja tersebut memberikan efek pada efisiensi dan efektivitas pelayanan publik. Dengan demikian kebutuhan masyarakat terhadap penyelenggaraan manajemen penganggaran publik harus berorientasi lebih luas, nyata, dan bertanggungjawab. Manajemen penganggaran publik pun harus dipahami sebagai hak dan kewenangan yang diberikan masyarakat kepada pemerintah, untuk mengelola dan mengatur semua potensi dan kekayaan yang ada untuk kesejahteraan dan kemakmuran masyarakat.

Disamping berbagai informasi terkait penganggaran tersebut, apabila ditelusuri secara mendalam, Islam telah memiliki sejarah dalam implementasi penganggaran dalam pemerintahan. Dalam sejarah awal pemerintaham Islam pada masa Nabi Muhammad SAW, khulafaurrasidin, sampai pada khalifah-khalifah selanjutnya, aktifitas pemerintahan tidak lepas dari manajemen penganggaran pemerintahan yang semata-mata untuk tujuan kemakmuran dan kesejahteraan bagi masyarakat pada saat itu.

Sumber pendapatan primer yang merupakan pendapatan utama bagi Negara saat itu berupa zakat dan ushur. Sedangkan sumber pendapatan sekunder berupa uang tebusan untuk para tawanan perang, pinjaman pembebesan kaum muslimin, khums atas rikaz, amwal fadhilah, wakaf, nawaib, jiayah, kharaj, zakat fitrah, shadaqah, kaffarat, ghanimah, dan fa'i(Dawwabah, 2010). Dengan demikian sesungguhnya Islam telah lebih baik awal memahami dan mengaktualisasikan konsep manajemen penganggaran publik, dengan segala kelebihan dan kekurangan dalam pelaksanaanya. Bercermin dari penjelasan dan uraian terkait manajemen penganggaran publik tersebut, baik konsep manajemen penganggaran secara umum ataupun penganggaran dalam perspektif Islam yang bersumber dari pemikiran dan implementasi yang dilakukan oleh Khalifah Umar bin Abdul Aziz, pada dasarnya memiliki karakteristik yang berbeda dengan sudut pandang yang berbeda pula pastinya, dan hal ini menjadi menarik untuk dikaji lebih serius, 
bagaimana seharusnya konsep manajemen penganggaran public dapat berjalan dengan baik.

\section{PEMBAHASAN}

\subsection{Manajemen Penganggaran Publik}

Manajemen penganggaran publik memiliki berbagai aspek yang perlu diperhatikan. Aspek yang paling utama dalam reformasi penganggaran (budgeting reform) adalah merubah pola penganggaran tradisional (traditional budget) kepada pola penganggaran berbasis kinerja (performance budget). Traditional budget lebih fokus pada penyusunan anggaran yang sifatnya line-item dan instrumentalism, yaitu proses dan prosedur penyusunan penganggaran yang hanya berorientasi untuk kebutuhan pengeluaran penganggaran semata, tanpa melihat kebutuhan yang sebenarnya. Hal ini sering kali bertentangan dengan kebutuhan riil dan kepentingan masyarakat. Diperlukan adanya perubahan paradigma penganggaran publik yang berorientasi pada kinerja, kepentingan, dan kebutuhan masyarakat. Diantara Paradigma manajemen penganggaran publik tersebut antara lain:

1. Penganggaran harus bertumpu pada kepentingan publik;

2. Penganggaran harus dikelola dengan hasil yang baik dan biaya rendah (work better and costless);

3. Penganggaran harus diberikan secara transparan dan akuntabel secara rasional untuk keseluruhan siklus anggaran;

4. Penganggaran harus dikelola dengan pendekatan kinerja (performance oriented) untuk seluruh jenis pengeluaran maupun pendapatan;

5. Penganggaran harus mampu menumbuhkan sikap profesionalisme kerja di setiap organisasi yang terkait.

Berdasarkan hal tersebut diperlukan adanya prinsip-prinsip yang menjadi dasar dalam manajemen penganggaran publik, diantaranya sebagai berikut:

1. Komprehensif dan disiplin; anggaran adalah satu-satunya mekanisme yang akan menjamin terciptanya disiplin pengambilan keputusan;

2. Fleksibilitas; Sampai tingkat tertentu, pemerintah harus diberi keleluasaan yang memadai sesuai dengan ketersediaan informasi-informasi yang relevan yang dimilikinya;

3. Terprediksi; Kebijakan yang memprediksi adalah faktor penting dalam peningkatan kualitas implementasi anggaran;

4. Kejujuran; Kejujuran merupakan etika dan moral yang menyangkut proyeksi 
pendapatan dan belanja anggaran;

5. Informasi; Informasi merupakan dasar kejujuran untuk melakukan proses pengambilan keputusan. Oleh karena itu, keteraturan pelaporan tentang biaya, output, dan kebijakan anggaran sangat diperlukan;

6. Transparansi dan Akuntabilitas; Transparansi lebih pada syarat untuk merumuskan kebijakan dengan pengetahuan dan permasalahan, serta informasi yang relevan untuk proses kebijakan yang dilaksanakan.

Prinsip-prinsip pokok yang menjadi dasar manajemen penganggaran publik tersebut memberikan arah pada perencanaan, penyusunan dan pelaksanaan penganggaran. Proses perencanaan, penyusunan, dan pelaksanaan penganggaran yang menyangkut aspirasi dan kepentingan masyarakat harus memenuhi kebutuhan hidup masyarakat dan dapat dipertanggungjawabkan kepada publik yang berarti bahwa proses penganggaran mulai dari perencanaan, penyusunan dan pelaksanaan harus benar-benar dapat dilaporkan dan dipertanggungjawabkan kepada masyarakat dalam bentuk evaluasi penganggaran. Dan masyarakat tidak hanya memiliki hak untuk mengetahui proses penganggaran tetapi berhak untuk menuntut pertanggungjawaban atas rencana dan pelaksanaan anggaran tersebut.

Prinsip-prinsip pokok dalam proses manajemen penganggaran publik juga harus memiliki sifat ekonomis, efesien dan efektif. Ekonomis yaitu berkaitan dengan mengklasifikasi pemanfaatan sumber daya dalam jumlah dan kualitas tertentu dengan berorientasi pada harga termurah. Efesien bermakna penggunaan dana dari masyarakat (public money) harus dapat memberikan hasil (output) yang maksimal dan berdaya guna. Efektif berarti penggunaan anggaran harus dapat mencapai target dan tujuan kepentingan publik/masyarakat.

Dengan demikian ada beberapa hal yang perlu ditekankan dalam tulisan ini, bahwa manajemen penganggaran publik merupakan proses panjang yang berlangsung yang perlu dievaluasi karena masih dianggap kurang memihak dan belum dinikmati oleh masyarakat luas, yang telah berkontribusi besar terhadap pendapatan anggaran. Manajemen penganggaran publik dalam tulisan ini mencoba memberikan alternatif solusi bagaimana seharusnya manajemen penganggaran publik dapat dikelola sebaik mungkin dengan pendekatan-pendekatan lain yang dapat memberikan kontribusi untuk perbaikan dimasa yang akan datang.

\subsection{Pemikiran Umar Bin Abdul Aziz Tentang Manajemen Penganggaran Publik}

Umar bin Abdul Aziz merupakan Khalifah yang sudah sering didengar di tengah- 
tengah masyarakat muslim dalam kerangka sejarah Islam. Para ulama di dalam buku-bukunya banyak yang menulis bagaimana kepemimpinan Khalifah Umar bin Abdul Aziz ini, dengan segala keberhasilan yang diraih selama menjadi khalifah. Catatan sejarah mengatakan bahwa Khalifah Umar bin Abdul Aziz telah berhasil mensejahterakan rakyatnya pada masa itu dan menjadi isu yang sangat menarik untuk dikaji dan diteliti lebih mendalam terkait sosok Umar bin Abdul Aziz ini.

Umar bin Abdul Aziz bin Marwan merupakan seorang khalifah yang saleh dan sering dipanggil dengan sebutan Abu Hafsh, dan Umar bin Abdul Aziz menjadi khalifah kedelapan pada masa pemerintahan Dinasti Umayyah, dan para ulama menyepakati bahwa Khalifah Umar bin Abdul Aziz merupakan Khalifah Rasyidin yang kelima. Umar bin Abdul Aziz dilahirkan di Hulwan, nama sebuah desa di Mesir, sedangkan ayahnya bernama Marwan yang pernah menjadi gubernur di wilayah itu (As-Suyuthi:2013). Umar bin Abdul Aziz menjadi khalifah pada masa dinasti Bani Umayyah selama dua setengah tahun, dengan usia pemerintahan yang relatif singkat tersebut, beliau berhasil mereformasi sendi-sendi kehidupan rakyatnya.

\subsubsection{Kebijakan Pengelolaan Penganggaran}

Pada masa pemerintahan Umar bin Abdul Aziz, pengelolaan pengenggaran dikelola oleh bait al-maal. Bait al-maal bukanlah lembaga privat atau swasta, melainkan sebuah lembaga yang mengurusi segala pemasukan dan pengeluaran dari negara Islam pada saat itu. Bait al-maal dalam pengertian ini, telah dipraktekkan dalam sejarah Islam sejak masa Rasulullah, diteruskan oleh para Khalifah sesudahnya, yaitu masa Abu Bakar, Umar bin Khattab, Usman bin Affan, Ali bin Abi Thalib, dan khalifah-khalifah selanjutnya, hingga kehancuran khilafah di Turki pada tahun 1924.

Pengelolaan bait al-maal pada masa Umar bin Abdul Aziz berbeda dengan masa- masa khalifah sebelumnya, beliau melakukan reformasi diberbagai bidang, sehingga terjadi perbaikan kehidupan rakyatnya. Kebijakan pengelolaan penganggargan pada masa Umar bin Abdul Aziz dibagi menjadi dua bagian, yaitu kebijakan yang berkaitan dengan sumber- sumber penerimaan bait al-maal dan kebijakan yang berkaitan dengan pengeluaran atau alokasi bait al-maal.

\subsubsection{Sumber Penerimaan Penganggaran}

Mengatur keuangan negara agar stabil sangat penting agar tidak terjadi kegoncangan perekonomian. Hal ini dibutuhkan agar roda pemerintahan tetap berjalan. Sisi pemasukan dan pengeluaran menjadi perhatian seorang pemimpin agar tidak terjadi defisit anggaran. Pada masa pemerintahan Umar bin Abdul Aziz, seluruh sumber-sumber penerimaan negara dioptimalkan, 
kemudian penggunaan anggaran dilakukan seefisien mungkin. Kebijakan efisiensi ini tidak hanya diberlakukan untuk para pegawainya saja, akan tetapi diawali dari dirinya sendiri, keluarganya, kemudian diterapkan dalam pemerintahannya. Sehingga kehidupan Umar bin Abdul Aziz sebagai khalifah sangat sederhana, padahal sebelum menjabat sebagai khalifah beliau adalah orang yang berkecukupan dan pernah menjabat sebagai gubernur Madinah. Sumber-sumber penerimaan negara pada masa pemerintahan Umar bin Abdul Aziz adalah sebagai berikut:

\section{a. Zakat}

Khalifah Umar bin Abdul Aziz mengikuti sunnah Nabi dalam hal penarikan zakat, menunjuk para petugas yang amanah dan dapat dipercaya, lalu menyuruh mereka untuk menarik harta yang diwajibkan untuk dizakatkan tanpa berlebih-lebihan atau bahkan mendz̧alimi. Kemudian Khalifah Umar bin Abdul Aziz memerintahkan para petugas untuk mencatatkan resi tanda pelunasan untuk para pembayarnya hingga mereka tidak harus membayar lagi kecuali telah berganti tahun. Lalu Khalifah Umar bin Abdul Aziz juga memastikan setiap kelompok yang berhak menerima zakat harus menerima zakat tersebut di daerahnya masing-masing kecuali mereka sudah berkecukupan (Ash Shalabi: 2014) Dasar kebijakan Khalifah Umar bin Abdul Aziz terkait zakat disandarkan pada firman Allah swt dalam al-Qur'an yang artinya:

"Dan dirikanlah shalat dan tunaikanlah rakat. Dan kebaikan apa saja yang kamu usabakan bagi dirimu, tentu kamu akan mendapat pahala nya pada sisi Allah. Sesungguhnya Alah Maha Melihat apa-apa yang kamu kerjakan.” (Al-Qur;an:1989)

Khalifah umar bin Abdul Aziz sangat menekankan agar rakyatnya membayar zakat, karena selain zakat merupakan perintah Allah swt langsung, zakat juga berdampak terhadap kesejahteraan rakyat lainnya. Pada dasarnya zakat juga dapat diartikan distribusi pendapatan, dimana orang yang memiliki harta berlebih berbagi dengan sesama muslim yang kurang mampu.

\section{Jizyah.}

Ketika Umar bin Abdul Aziz menjabat sebagai Khalifah, beliau segera menghapuskan kewajiban jizyah bagi orang-orang yang sudah masuk Islam. Bahkan Umar bin Abdul Aziz menekankan larangan itu. Ia pernah menuliskan sebuah surat kepada pejabatnya yang isinya antara lain: "Apabila ada shalat dengan menghadap kiblat kita, maka janganlah sekali-kali kamu mewajibkan jizyah kepadanya. 
Jizyah merupakan salah satu sumber penerimaan negara pada masa pemerintahan Umar bin Abdul Aziz. Jiøyah wajib diambil dari orang-orang kafir, selama mereka tetap kufur, namun apabila memeluk Islam, maka gugurlah jizyah dari mereka. Untuk besarnya jisyah, tidak ditetapkan dengan suatu jumlah tertentu, namun ditetapkan berdasarkan kebijakan dan ijtihad khalifah, dengan catatan tidak melebihi kemampuan orang yang wajib membayar jizyah. Apabila jizyah diberlakukan pada orang yang mampu, sementara ia keberatan membayarnya, maka ia tetap dianggap mempunyai hutang terhadap jizyah tersebut. Ia akan diperlakukan sebagaimana orang yang mempunyai hutang.

\section{Kharaj.}

Kharaj juga merupakan sumber pemasukan negara pada masa pemerintahan Umar bin Abdul Aziz, bahkan pendapatan negara dari kharaj ini sangat tinggi. Kharaj ini berbeda dengan 'ushur, karena kharaj adalah hak kaum muslimin atas tanah yang ditaklukkan dari orang kafir, baik melalui peperangan maupun damai. Pada masa pemerintahan Umar bin Abdul Aziz, pemasukan kas negara dari segi kharaj begitu tinggi, bahkan hingga mencapai seratus dua puluh empat juta dirham. Bertambahnya pemasukan kas negara dari kharaj ini disebabkan oleh siasat reformasi yang dicanangkan oleh Khalifah Umar bin Abdul Aziz, yang mana salah satunya adalah melarang jual beli tanah kharaj. Larangan itu ternyata dapat memelihara sumber utama produksi pertanian, dan larangan itu juga dirasakan oleh petani sebagai perhatian terhadap mereka, sebab disamping larangan tersebut Khalifah Umar bin Abdul Aziz juga menghapuskan segala macam bentuk pajak yang dॄ̧halim yang sebelumnya sangat mengganggu produksi pertanian mereka.

\section{4. 'Ushur.}

Ushur merupakan apa yang diambil atas hasil pertanian tanah ushriyyah. Dalam buku Ali Muhammad Ash Shalabi (2014) dikemukakan bahwa Umar bin Abdul Aziz juga menekankan perhatiannya terhadap 'ushur yang menjadi salah satu pemasukan negara, ia menjelaskan dasar-dasar hukumnya kepada para petugasnya, ia juga memerintahkan untuk menuliskan bukti pembayaran kepada mereka yang telah membayarkannya hingga mereka tidak membayar lagi dalam jangka waktu satu tahun ke depan. Khalifah Umar bin Abdul Aziz juga menegaskan larangannya kepada para petugas itu agar mereka tidak menarik 'ushur dengan cara-cara yang tidak benar.

\section{Ghanimah dan Fa'i.}

Beberapa ulama berpendapat bahwa ghanimah merupakan segala harta kekayaan orang-orang kafir yang dikuasai oleh kaum muslimin melalui perang penaklukan. Pihak yang berwenang mendistribusikan ghanimah adalah Rasulullah SAW dan para khalifah 
setelah beliau. Sedangkan fa'i merupakan segala harta kekayaan orang-orang kafir yang dikuasai oleh kaum muslimin tanpa peperangan. Ketika Umar bin Abdul Aziz menjabat sebagai Khalifah, ia lebih mementingkan reformasi keadaan di dalam negeri, hingga tidak banyak terjadi perluasan wilayah di masa pemerintahannya. Oleh karena itu pula, tidak banyak harta ghanimah yang masuk ke dalam kas negara pada masa pemerintahan Khalifah Umar bin Abdul Aziz, harta ghanimah yang ada di bait al-maal saat itu adalah sisa-sisa dari perluasan wilayah Islam yang dilakukan oleh para Khalifah sebelumnya.

\section{Pajak (dharibah).}

Pajak (dharibah) merupakan salah satu sumber pemasukan bait al-maal. Sebagaimana sumber penerimaan yang sudah diuraikan diatas, pajak juga sangat dibutuhkan untuk membiayai berbagai kebutuhan negara pada saat itu. Akan tetapi pajak yang dipungut memiliki beberapa perbedaan dibandingkan dengan sumber penerimaan lainnya.

\subsubsection{Distribusi Pengeluaran Penganggaran}

Pengeluaran bait al-maal pada masa Khalifah Umar bin Abdul Aziz banyak digunakan untuk kesejahteraan rakyatnya, sehingga setiap pemasukan bait al-maal, Khalifah Umar bin Abdul Aziz selalu berupaya untuk menyalurkannya segera kepada masyarakat yang membutuhkan. Kebijakan pengeluaran bait al-maal pada umumnya dibagai menjadi dua, yaitu untuk kepentingan masyarakat umum dan untuk kepentingan negara. Khalifah Umar bin Abdul Aziz selalu memikirkan tentang nasib kaum fakir miskin, anak yatim, janda-janda, dan lain sebagainya. Pengeluaran bait al-maal juga dilakukan secara transparan, sehingga para pegawainya juga dilarang untuk berbuat tidak adil dalam mengelola baital-maal.

\subsection{Dampak Kebijakan Penganggaran}

Dampak dari kebijakan-kebijakan yang dilakukan Khalifah Umar bin Abdul Aziz dirasakan langsung oleh rakyatnya. Permasalahan rakyatnya benar-benar diperhatikan oleh Umar bin Abdul Aziz, sehingga waktu kerjanya tidak memperhatikan siang dan malam. Umar bin Abdul Aziz juga sangat takut terhadap Allah swt, sehingga amanah yang diembannya benarbenar dijalankan dengan sangat maksimal. Pemerintahan Umar bin Abdul Aziz juga banyak dicatat oleh para ulama sebagai pemerintahan yang fenomenal dan bersejarah. Khalifah Umar bin Abdul Aziz memimpin selama dua setengah tahun, waktu yang relatif singkat. Pada masa pemerintahan Umar bin Abdul Aziz telah diuraikan diatas terlebih dahulu terkait berbagai kebijakan yang dilakukan oleh Umar bin Abdul Aziz. Oleh karena itu perlu dilihat apakah dampak-dampak yang dirasakan dari kebijakan Khalifah Umar bin Abdul Aziz. 
Berikut diuraikan beberapa dampak kebijakan pengelolaan keuangan publik terkait dengan penganggaran masa Khalifah Umar bin Abdul Aziz:

Kesejahteraan Rakyat Meningkat. Pada masa pemerintahan sebelum Umar bin Abdul Aziz, kondisi kerakyatnya sangat jauh meningkat. Hal ini ditandai dengan orang kaya sulit untuk menyalurkan sedekahnya karena orang-orang yang dahulunya penerima sedekah sudah menjadi orang yang mampu. Kondisi tersebut tentu sangat berbeda dengan apa yang ada saat ini, dimana banyak sekali pengemis/peminta-minta ditemukan dijalan raya, pasar, tempat-tempat umum dan lain sebagainya. Untuk melihat gambaran kesejahteraan rakyat Umar bin Abdul Aziz, berikut pernyataan salah seorang putera Zaid bin Khattab dalam buku Herfi Ghulam Faizi (2012): Umar bin Abdul Aziz menjadi Khalifah hanya dua setengah tahun. Itu sama artinya dengan tiga puluh bulan. Tidaklah ia meninggal sampai ada seorang ketika itu yang menitipkan hartanya kepada kami dalam jumlah besar. Ia berpesan: "Bagikan ini kepada orang-orang fakir." Sampai malam hari ia menunggu siapa orang yang akan diberinya harta sedekah itu tapi tidak menemukan. Akhirnya ia pulang membawa kembali harta yang ia niatkan untuk disedekahkan itu. Sungguh Umar bin Abdul Aziz telah membuat manusia menjadi kaya.

Daya Beli Masyarakat Meningkat. Kesejahteraan masyarakat meningkat juga ditandai dengan daya beli masyarakat yang meningkat. Meningkatnya daya beli masyarakat disebabkan karena pendapatan masyarakat yang meningkat yang berpengaruh pada pendapatan negara. Meningkatnya pendapatan juga akan meningkatkan kesadaran masyarakat untuk membayar zakat, shadaqah dan lain sebagainya melalui bait al-maal, sehingga secara langsung meningkatkan pendapatan negara. Sesungguhnya manajemen ekonomi Umar bin Abdul Aziz telah membuahkan hasil yang bisa dinikmati oleh seluruh masyarakat pada saat itu, dengan fasilitasfasilitas yang dapat mendukung produktivitas dan kreatifitas masyarakat. Dukungan tersebut memberikan efek peningkatan sektor perdagangan yang berimbas pada pertumbuhan ekonomi dan sektor lainnya. Dengan demikian pendapatan masyarakat pun akan meningkat, dan berefek pada bertambah pula zakat yang harus dikeluarkan oleh masyarakat dari harta mereka.

Kemiskinan Berkurang. Saat itu Khalifah Umar bin Abdul Aziz mencanangkan program bantuan kepada orang-orang miskin. Bagi siapapun orang yang dililit hutang dan tak mampu mengembalikannya maka pemerintah akan membantunya dalam mengembalikan hutanghutangnya itu. Tentu ini adalah salah satu program untukmenyelamatkan danmeningkatkan perekonomian rakyat. Hingga akhirnya datang sebuah surat dari salah seorang pegawainya yang diantara isinya adalah sebagaimana berikut ini:

"Wahai Amirul Mukminin, sesungguhnya kami mendapati orang yang mempunyai rumah, 
Yusup. Manajemen Penganggaran Publik

pembantu, perabotan rumah tangga yang lengkap serta kendaraan. Apakah mereka perlu dibantu untuk mengembalikan butangnya?" Khalifah menjawab: "Seorang muslim itu harus mempunyai rumah untuke berteduh, pembantu yang membantunya sehari-hari, kuda untuk berjihad melawan musub serta perabotan untuk rumab-nya. Maka yang seperti itu jika memiliki butang tetaplab seorang yang perlu dibantu.".

Pajak Berkurang Karena Banyak yang Masuk Islam. Inilah salah satu fenomena yang terjadi pada masa pemerintahan Khalifah Umar bin Abdul Aziz. Banyaknya orang yang berbondong-bondong masuk ke dalam agama Islam, tentunya ada sebab kenapa mereka melakukan itu. Di antaranya adalah karena mereka menyaksikan keindahan, kesempurnaan, dan kebaikan Islam, yang itu belum mereka lihat dengan jelas sebelumnya. Melihat fenomena ini, 'Adi bin Arithah menyampaikan masukan kepada Khalifah Umar bin Abdul Aziz. Sungguh orang-orang telah banyak yang masuk Islam, aku khawatir jika pendapatan negara dari pajak menjadi berkurang. Namun Umar bin Abdul Aziz memiliki sudut pandang tersendiri menanggapi fenomena sosial yang mencengangkan ini. Ia pun segera membalas surat 'Adi bin Arithah dengan mengatakan, "Aku telah memahami suratmu. Demi Allah, aku lebih senang semua umat manusia masuk Islam, sehingga aku dan kamu menjadi petani yang makan dari hasil jerih payah sendiri."

Terciptanya Kenyamanan dan Keamanan Sosial. Salah satu indikator keberhasilan pemerintahan Umar bin Abdul Aziz adalah terciptanya kenyamanan dan keamanan sosial. Pada masa pemerintahan Umar bin Abdul Aziz, Islam dikembangkan tidak dengan peperangan akan tetapi beliau lebih banyak fokus kepada perbaikan di internal. Umar pun dikenal dengan kecerdasan, kematangan berfikir dan kebijaksanaan bersikap. Kebijaksanaan Umar bin Abdul Aziz terbukti ketika terjadi pemberontakan yang semakin memanas ketika kekhilafahan Islam dipegang oleh Yazid bin Muawwiyah. Karena disana Abdullah bin Zubair juga memproklamirkan diri sebagai Khalifah atas dukungan masyarakat Madinah. Namun dengan kecerdasan, kematangan berpikir, kebijaksanaan bersikap, akhirnya Umar bin Abdul Aziz berhasil merangkul kelompok ini dalam pangkuan Islam yang benar. Sejarah telah mencatat dengan rapi, bahwasanya masa pemerintahan Umar bin Abdul Aziz ini terkenal dengan keamanan dan kenyamanan sosialnya. Keamanan yang menyeluruh dan kenyamanan yang merata. Hal itu disebabkan oleh sikap adilnya dalam memimpin, semangatnya dalam memerangi kedhaliman, perhatiannya yang besar akan kebutuhan masyarakat.

Dengan demikian Khalifah Umar bin Abdul Aziz yang memimpin umat hanya dalam kurun waktu dua setengah tahun, telah memberikan kebijakan dan perubahan arah pengelolaan penganggaran yang sangat luar biasa. Hal ini dibuktikan dengan penerimaan negara yang 
diperoleh melalui zakat sebagai sumber utama pendapatan negara, mengoptimalkan sumbersumber penerimaan negara lainnya, seperti jiayah, kharaj, 'ushur, ghanimah/fa'i dan pajak. Sedangkan kebijakan yang berkaitan dengan pengeluaran negara/alokasi bait al-maal pada umumnya dibagi menjadi dua, yaitu pengeluaran untuk kepentingan masyarakat umum dan pengeluaran untuk kepentingan negara, yang kesemua pengeluaran tersebut semata-mata untuk keadilan dan kesejahteraan umat. Dampak dari kebijakan-kebijakan yang dilakukan oleh Khalifah Umar bin Abdul Aziz memberikan efek pada kesejahteraan rakyat yang meningkat, daya beli masyarakat meningkat, orang miskin berkurang, pajak berkurang karena banyak yang masuk Islam, munculnya keamanan dan kenyamanan sosial, datangnya pertolongan dari Allah/ kemenangan, dan lain sebagainya. Gambaran tentang pengelolaan penganggaran pada masa Khalifah Umar bin Abdul Aziz tergambar dalam tabel berikut:

Tabel 1. Penganggaran Masa Khalifah Umar bin Abdul Aziz (As-Suyuthi, 2013)

\begin{tabular}{ll}
\hline Pendapatan/Inovasi & Posisi/Distribusi \\
\hline Lembaga Bait al-Maal & \\
Zakat & Kepentingan MasyarakatUmum \\
Jizyah & \\
Kharaj & \\
Ushur & \\
Pajakimah dan Fa'i' & KepentinganNegara \\
Sumber Pendapatan & Pengeluaran \\
Zakat dan Ushr. & Pendistribusiannya untuk lokal jika \\
Khums dan Shadaqah & berlebihan disimpan. \\
Kharaj, Fa'i, Jizyah, Ushr, Sewa & Fakir Miskin dan Kesejahteraan. \\
Tetap. & Dana Pensiun dan DanaPinjaman \\
Pendapatan dari semua sumber. & Pekerja, pemelihara anak terlantar dan \\
\end{tabular}

Beberapa kebijakan Khalifah Umar bin Abdul Aziz berdasarkan pola penganggaran publik termaktub dalam tabel di atas adalah sebagai berikut:

1. Bait al-maal bukan lembaga privat atau swasta, melainkan lembaga yang mengurusi segala pemasukan dan pengeluaran darinegara;

2. Kebijakan pengelolaan penganggaran dibagi menjadi dua bagian, yaitu: kebijakan yang berkaitan dengan sumber-sumber penerimaan bait al-maal dan kebijakan yang berkaitan dengan pengeluaran atau alokasi baital-maal;

3. Sumber-sumber penerimaan negara harus dioptimalkan, dan penggunaan anggaran dilakukan seefisien mungkin; 
4. Pemberlakuan efisensi diberlakukan bagi semua, mulai dari khalifah, pejabat negara dan semua masyarakat;

5. Menyegerakan pengeluaran anggaran negara untuk kepentingan masyarakat;

6. Transparansi pengelolaan anggaran negara;

7. Menghapus Jiayah bagi orang yang sudah masuk Islam;

8. Melarang jual beli tanah kharaj.

Sedangkan output kebijakannya adalah sebagai berikut:

1. Kesejahteraan masyarakat meningkat;

2. Daya beli masyarakat meningkat:

3. Orang miskin berkurang;

4. Pajak berkurang karna banyak yang masuk Islam;

5. Terciptanya kenyamanan dan keamanan sosial

Sebagai analisa dan pembanding manajemen penganggaran publik dan manajemen penganggaran publik perspektif Islam, terlebih dahulu penulis menyampaikan gambaran tentang contoh skema postur APBD di Indonesia. Skema postur APBD Indonesia di Tabel 2 memberikan gambaran betapa banyaknya instrumen belanja dibandingkan pendapatan, ini dapat memberikan efek negatif pada manajemen penganggaran publik, dengan munculnya defisit pada pengelolaan keuangan publik. Berdasarkan skema postur penganggaran publik tersebut, alternatif terbaik untuk mengantisipasi terjadinya defisit pada penganggaran publik adalah dengan mengoptimalkan peran dan fungsi zakat, infaq, dan shadaqah dalam postur penganggaran publik.Zakat menjadi sangat penting fungsinya jika dioptimalkan dan dimksimalkan sebagai pendapatan pemerintah yang primer. Di bawah ini terdapat gambaran atau skema analisis fungsi dan peran zakat dalam postur manajemen penganggaran publik.

Tabel 2. Pendapatan \& Belanja Nasional

\section{Pendapatan Nasional/ Daerah}

\section{Pendapatan Asli Daerah (PAD)}

1. Pajak Daerah

2. Retribusi Daerah

3. Hasil Pengelolaan Kekayaan yg dipisahkan

4. Lain-lain PAD yang sah

\section{Dana Perimbangan}

1. Dana bagi Hasil Pajak/Bagi Hasil bukan Pajak

2. Dana Alokasi Umum

3. Dana Alokasi Khusus 


\section{Lain-lain Pendapatan Daerah Yang Sah}

1. Hibah

2. Dana Bagi Hasil Pajak dari Provinsi

3. Dana Penyesuaian dan Otonomi Khusus

4. Bantuan Keuangan dari Provinsi

Belanja Nasional/ Daerah

\section{Belanja Tidak Langsung}

1. Belanja Pegawai

2. Belanja Bunga

3. Belanja Hibah

4. Belanja Bantuan Sosial

5. Belanja Bagi Hasil ke Provinsi

6. Belanja Bantuan Keuangan ke Provinsi

7. Belanja Tak Terduga

\section{Belanja Langsung}

1. Belanja Pegawai

2. Belanja Barang/Jasa

3. Belanja Modal

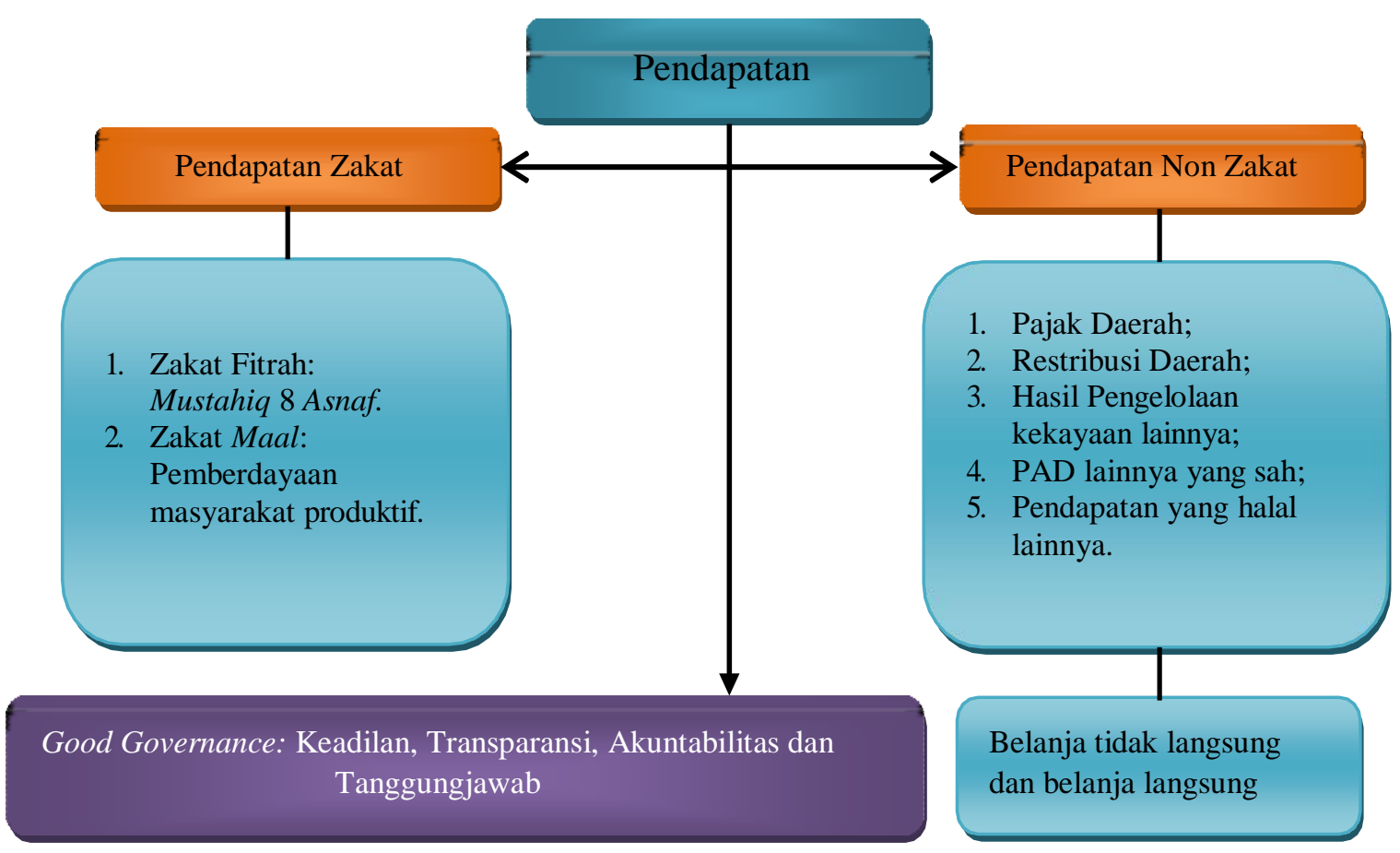

Gambar 1. Fungsi dan Peran Zakat dalam Postur

Manajemen Penganggaran Publik 
Tabel 3. Pendapatan dan Belanja Daerah

\section{PENDAPATAN DAERAH}

\section{Pendapatan Asli Daerah (PAD)}

1. Zakat:

a. Zakat Fitrah

b. Zakat $M a>l$

2. Non Zakat:

a. Pajak Daerah

b. Retribusi Daerah

c. Hasil Pengelolaan Kekayaan Daerah

d. Lain-lain PAD yang Sah dan Halal

Dana Perimbangan

1. Dana Bagi Hasil Pajak dan Bukan Pajak

2. Dana Alokasi Umum dan Khusus

Lain-lain Pendapatan Daerah Yang Sah dan Halal

1. Hibah, Shadaqah dan Wakaf

2. Dana Bagi Hasil Pajak dari Provinsi

3. Dana Otonomi Khusus

4. Bantuan Keuangan dari Provinsi

\section{BELANJA DAERAH}

\section{Belanja Tidak Langsung}

1. Belanja Pegawai Pemerintah

2. Belanja Hibah

3. Belanja Bantuan Sosial

4. Belanja Pendidikan dan Kesehatan

5. Belanja Bagi Hasil ke Provinsi

6. Belanja Keadaan Darurat

\section{Belanja Langsung}

1. Belanja Pegawai Non Pemerintah

2. Belanja Barang dan Jasa

3. Belanja Modal

Tabel 4. Instrumen Pendapatan Modern

Pendapatan Asli Daerah (PAD) Instrumen Pendapatan Modern

\begin{tabular}{ll}
\hline Zakat, infaq, dan & Murakki: Profesi \\
Shadaqah & Tabungan/Uang \\
& Saham dan Obligasi \\
& Investasi \\
& Industri
\end{tabular}




\begin{tabular}{|c|c|}
\hline Mustahiq (8 Asnaf) & Insrumen Belanja Modern \\
\hline \multirow[t]{5}{*}{ Fakir dan Miskin } & Jaminan kesehatan. \\
\hline & Jaminan kebutuhan masyarakat. \\
\hline & Pemberdayaan potensi masyarakat. \\
\hline & Pemberdayaan ekonomi kerakyatan. \\
\hline & Semua instrumen pengentasan kemiskinan. \\
\hline \multirow[t]{4}{*}{ 'Amil } & Gaji pegawai pemerintah. \\
\hline & Gaji pegawai nonpemerintah. \\
\hline & Semua instrumen biaya lagsung dantidak \\
\hline & langsung. \\
\hline \multirow[t]{4}{*}{ Muallaf } & Pembinaan keislaman. \\
\hline & Pemberdayaan aktifitas keagamaan. \\
\hline & Semua instrumen pembinaan dan \\
\hline & pemberdayaan muallaf \\
\hline \multirow[t]{4}{*}{ Riqab } & Tenaga kerja yang terlantar dan \\
\hline & berrmasalah. \\
\hline & Semua instrumen dalam urusan \\
\hline & keimigrasian. \\
\hline \multirow[t]{3}{*}{ Gharim } & Hutang Rentenir. \\
\hline & Semua instrumen dalam urusan hutang bagi \\
\hline & masyarakat yang tidak mampu. \\
\hline \multirow[t]{4}{*}{ Sabilillah } & Kegiatan Sosialisasi Kemasyarakatan. \\
\hline & Biaya Pendidikan Dasar, Menengah,dan Tinggi. \\
\hline & Semua instrumen pembangunan karakter \\
\hline & masyarakat. \\
\hline \multirow[t]{3}{*}{ Ibnu Sabil } & Bantuan/ Beasiswa \\
\hline & Semua instrumen bantuan yang sifatnya untuk \\
\hline & kemajuan sumber daya manusia di daerah. \\
\hline
\end{tabular}

Dengan demikian, konsep dan teori manajemen penganggaran publik dalam perspektif Islam, sesungguhnya dapat dilakukan dan di implementasikan ke semua bidang dan aktifitas pemerintahan, dengan berpedoman pada pengelolaan penganggaran publik yang baik, transparan, bersih dan berorientasi pada kesejahteraan dan kemakmuran untuk masyarakat 
banyak, tanpa membedakan keyakinan dan kemampuan masyarakatnya. Dan yang perlu dicatat adalah bahwa konsep dan teori dalam Islam sudah pasti mampu menjawab dan bersinergi dengan konsep dan teori apapun. Hal tersebut menjadi penting untuk dapat dijadikan solusi alternatif untuk menjawab semua permasalahan-permasalahan yang muncul.

Berdasarkan paparan dan analisis pada tulisan ini, beberapa kesempulan dapat disampaikan sebagai berikut: Mekanisme perencanaan, pelaksanaan, dan evaluasi manajemen penganggaran publik, yang diawali melalui proses musyawarah perencanaan penganggaran, sampai pada tahap penetapan penganggaran harus lebih megedepankan konsep good governance sebagai orientasi manajemen penganggaran publik. Untuk menuju capaian konsep good government tersebut diperlukan adanya community government yang dilaksanakan oleh pemerintah, dalam rangka mewujudkan masyarakat yang berkualitas dan berintegritas yang mampu bersinergi dengan pemerintah dalam mewujudkan cita-cita pembangunan, mengoptimalkan seluruh potensi yang dimiliki untuk kepentingan kesejahteraan dan kemakmuran masyarakat.

Reformasi manajemen penganggaran publik dalam perspektif Islam, merupakan perpaduan mekanisme pola perencanaan, pelaksanaan, dan evaluasi manajemen penganggaran publik yang telah berjalan, dengan konsep penganggaran pada masa Khalifah Umar bin Abdul Aziz yang diafiliasikan dalam konteks penganggaran modern, dengan memaksimalkan potensi yang bersumber dari masyarakat berupa zakat, wakaf, shadaqah, hibah, pajak (kharaj), baik pertanian, perdagangan, jasa, maupun industri yang halal. Hal ini sesuai dengan apa yang disampaikan oleh Abu Ubaid dalam kitab al-Amwal, yaitu as-sunuf al-amwal allati yaliha al-a'immah li ar-ra'iyyah, bahwa segala bentuk kekayaan yang dikelola oleh negara atau pemerintah adalah untuk kepentingan rakyat. Begitu juga pernyataan yang disampaikan oleh Muhammad Asraf Dawwabah dalam kitabnya al Iqtishad al Islamy madkhalun wa manhajun, yang menyampaikan tentang sumber-sumber pendapatan berupa pendapatan primer (zakat dan ushr), dan pendapatan sekunder (khums, jizyah, wakaf, shadaqah, dan ghanimah). Dan sumber-sumber pendapatan tersebut sudah pasti berorientasi pada maslabah dan menghindari masyaqqah, serta berpegang pada kaidah al-ghurmu bi al-ghurmi (akuntabilitas), dan kaidah malla al-yatimu al-wajib illa bibi fabuwaal-wajib.

Dengan demikian dari semua sumber pendapatan penganggaran dalam perspektif Islam, instrumen zakat, infaq, dan shadaqah merupakan sumber penerimaan pendapatan yang dapat dilaksanakan menjadi sumber pendapatan alternatif pada postur pendapatan asli. Sedangkan pengeluaran atau belanja dari instrumen zakat, infaq, dan shadaqah tersebut dapat dipergunakan sebagai instrumen pada program pemerintah dalam rangka menurunkan angka kemiskinan melalui pemberdayaan ekonomi masyarakat, sosial kemasyarakatan, pendidikan dan kesehatan. 
Termasuk juga untuk pengeluaran atau belanja langsung dan tidak langsung dalam bentuk gaji/upah bagi pegawai pemerintah.

Implikasi teoritik berdasarkan kesimpulan yang telah diuraikan tersebut dalam kerangka melanjutkan dan mengkolaborasikan konsep, teori dan implementasi manajemen penganggaran publik, dengan konsep dan teori penganggaran dalam perspektif Islam. Penganggaran dalam Islam sesungguhnya telah banyak ditulis dan disampaikan dalam sejumlah karya keislaman. Abdul Wahhab Khalaf misalnya, memberikan pernyataan bahwa politik anggaran (keuangan) bagi suatu pemerintahan merupakan upaya untuk mengatur sumber pendapatan, dan merealisasikannya dalam bentuk jaminan kebutuhan kepada masyarakat, tanpa adanya diskriminasi individu maupun kelompok. Karya lain terkait penganggaran dalam Islam juga disampaikan oleh Muhammad Asraf Dawwabah dalam kitabnya al Iqtishad al Islamy madkhalun wa manhajun, yang berisi penjelasan sumber- sumber pendapatan berupa pendapatan primer (zakat dan ushr), dan pendapatan sekunder (khums, jizyah, wakaf, shadaqah, dan ghanimab). Diperkaya juga dengan karya Abu Yusuf yang membahas panjang lebar tentang konsep, teori dan implementasi al-kharaj. Begitu pula dalam kitab fenomenal yang ditulis oleh Abu 'Ubaid yaitu al-Amwal yang menjelaskan tentang bagaimana pengelolaan penganggaran publik dalam perspektif Islam.

\section{SIMPULAN}

Konstruk penganggaran dalam sejarah Islam secara formal, memang belum ditemukan bentuknya, tetapi dasar-dasar penganggaran publik dalam Islam yang disebut dengan al-Siyasah al-maliyah menjadi fakta bahwa sesungguhnya Islam telah lebih awal memiliki konsep dasar dalam manajemen penganggaran publik, baik pada masa Rasulullah saw, sampai pada masa sahabat dan para khalifah setelahnya. Penelitian ini memadukan konsep dan teori antara manajemen penganggaran publik dengan manajemen penganggaran dalam perspektif Islam, berupa norma dan etika, bahkan pada tataran praktis, dalam bentuk optimalisasi potensi yang dimiliki, dan belum terkelola dengan baik oleh pemerintah, berupa zakat, wakaf, shadaqah, hibah, pajak (kharaj), dan lain sebagainya. Ini berbeda dengan teori yang disampaikan oleh Abu Yusuf yang menyatakan bahwa tidak ada perbedaan antara penganggaran publik dalam Islam maupun penganggaran publik pada umumnya, ini sesuai dengan kaidah fiqih yang disampaikannya yaitu tasarruf al-imam ala ra'iyyah manutun bi al-mashlahah, bahwa pada setiap kebijakan yang dilakukan oleh pemerintah sudah barang tentu untuk kemaslahatan bagi rakyat. Maknanya bahwa alokasi penganggaran keuangan publik harus terdistribusi dengan baik, adil, dan merata demi terwujudnya kesejahteraan dan kemakmuran bagi masyarakat banyak. Perpaduan kedua konsep 
Yusup. Manajemen Penganggaran Publik

dan teori tersebut, memunculkan konsep dan teori manajemen penganggaran publik baru, dengan konsep dan teori mashlahah, berkeadilan, menghindari masyaqqah, dan memiliki keseimbangan (equilibrium), untuk mencapai kesejahteraan dan kemakmuran masyarakat.

\section{REFERENSI}

Ali, Nuruddin. 2006. Zakat sebagai Instrumen dalam Kebijakan Fiskal. Jakarta: PT. Raja Grafindo Persada.

Amir, Muhammad Fakhri. 2019. Faktor Dominan Tingkat Pendapatan Mustahiq Penerima Zakat Produktif. Iqtishaduna. Vol. 10, No. 2. 151-160.

As-Suyuthi. 2013. Tarikh Khulafa: Sejarah Penguasa Islam. Jakarta: Pustaka Pelajar, 2013.

Dawwabah, Muhammad Asraaf, Al Iqtishad al Islamy Madkhalun wa Manhajun (Cairo: Darussalam, 2010).

Departemen Agama RI. 1989. Al-Qur'an dan Terjemah. Semarang: Toha Putra.

Faizi, Herfi Ghulam. 2012. Umar bin Abdul Aziz, 29 Bulan Mengubah Dunia. Jakarta: Cahaya Siroh, 28-31.

Hasbi, Al-Furqan. 2008. Masalah Zakat. Solo: PT Tiga Serangkai Pustaka Mandiri.

Inayah, Gazi. 2003. Teori Komprehensif tentang Zakat. Yogyakarta: Tiara Wacana.

K, Amiruddin. 2015. Model-model Pengelolaan Zakat di Dunia Muslim. Abkam. Vol. 3, No. 1. Juli. 139-166.

Mahmud, Abdul al-Hamid. 2006. Ekonomi Zakat Sebuah Kajian Moneter dan Kenangan Syariah. Jakarta: PT Raja Grafindo Persada.

Mardiasmo. 2002. Otonomi dan Manajemen Kenangan Daerah. Yogyakarta: CV. ANDI Offset, 2002, 33.

Nawawi, Ismail. 2010. Manajemen Publik: Kajian Teori, Reformasi, Strategi dan Implementasi. Surabaya: PMN, 145.

Pusat Pengkajian dan Pengembangan Ekonomi Islam (P3EI). 2008. Ekonomi Islam. Yogyakarta: P3EI.

Rafi', Mu’inan. 2011. Potensi Zakat: Perspektif Hukum Islam. Yogyakarta: Citra Pustaka.

Shalabi, Ali Muhammad. 2014. Perjalanan Hidup Khalifah yang Agung Umar bin Abdul Aziz; Ulama dan Pemimpin yang Adil. Jakarta: Darul Haq.

Shalabi, Ali Muhammad. 2014. Umar bin Abdul Aziæ: Khalifah Pembaru dari Bani Umayyah. Jakarta: Pustaka Pelajar.

Yin, R.K. 2011. Qualitative Research From Start to Finish. The Guilford Press. 